\title{
ENGINEERING GEOLOGICAL TYPIFICATION OF TERRITORIES FOR ALLOCATION OF MUNICIPAL SOLID WASTE MANAGEMENT FACILITIES (WITH THE EXAMPLE OF CENTRAL RUSSIA)
}

\author{
Irina Kozliakova*, Irina Kozhevnikova, Olga Eremina, Nadezhda Anisimova ${ }^{4}$ \\ ${ }^{1}$ Russian Academy of Sciences, Sergeev Institute of Environmental Geoscience, Laboratory for Exogenous \\ Geodynamics and Geological Risk Analysis. Russia.
}

Received 3 April 2020; received in revised form 16 October 2021; accepted 18 November 2021

\begin{abstract}
The article discusses methodological principles of typifying and zoning territories by suitability of engineering geological conditions for the allocation of municipal solid waste (MSW) management facilities in the Central Federal District (CFD) of the Russian Federation. The suitability of territories for municipal solid waste disposal is assessed according to the presence of weakly permeable deposits in the geological cross-section and their occurrence mode. A "map of engineering geological zoning CFD by the conditions of allocation MSW disposal sites and utilization facilities" has been compiled to a scale 1:2500000. The map gives a general indication of the suitability of the planned sites for waste disposal within the regarded region; it shows that, for the bulk of territory, the allocation of MSW disposal and management facilities requires undertaking additional measures for the geoenvironment protection from contamination.
\end{abstract}

Keywords: municipal solid waste; waste management; waste storage and reprocessing facilities; favorability of geoenvironment, Central Federal District, engineering geological zoning and mapping.

\footnotetext{
*Correspondence to: Irina Kozliakova. E-mail: kozliakova.sieg@ro.ru
} 


\section{INTRODUCTION}

The management of municipal solid waste appears to be one of the major ecological problems at present. A lot is said about how to solve the issue (Khmelchenko, 2018; Osipov, 2019). Selecting sites for the disposal of municipal solid wastes or waste utilization facilities is one of the most contentious aspects of waste management. Experts all over the world are attracted to research aimed at providing safe and environmentalfriendly waste management (Cremiato et al., 2018; Nakhaei et al., 2015; Ogola et al., 2011; Yannah et al., 2019). The complexity of the municipal solid waste (MSW) storage problem results, above all, from being multidisciplinary, that is, many social, economic, technical and environmental issues must be taken into consideration. A lot of works have proven the necessity of performing multi-criteria analysis for waste disposal site selection (Ghobadi et al., 2017; Khan \& Samadder, 2014; Kontos et al., 2005; Rahmat et al., 2017). Lately, in many countries around the world, the multi-criteria approach combined with geoinformational system (GIS) technologies are used for waste disposal site selection, which have proved their efficiency in finding a relevant and appropriate locations (Deswal \& Laura, 2018; El Maguiri et al., 2016; Güler \& Yomralığlu, 2017; Khodaparast et al., 2018).

Engineering geological conditions is one of the criteria involved in selecting an appropriate site, and in practice is one of the last taken into consideration. Priority is given to the distance from settlements and water reservoirs (remoteness), as well as natural reserves and protected areas. The geological environment degrades much more slowly than surface features do. At the same time, geological environment, that is, rocks and groundwater, are able to accumulate hazardous components for a long time and become prerequisites for future ecological disasters for future generations. By underestimating the impacts waste disposal has on the geoenvironment now, we create danger for ecological safety in the future.

The aim of the present study is to develop the methodology to assess the natural protection of the geological environment from contamination upon the implementation of large ecological projects due to the allocation of MSW utilization facilities. The case of the Central Federal District of Russia is taken as an example.

Storage at disposal sites still remains to be the main method of municipal solid waste treatment in Russia. The current waste management system cannot cope with the large amount of waste produced. The problem of waste management is most acute in the Central Federal District (CFD) of the Russian Federation, which covers an area of more than 650 thousand sq. $\mathrm{km}$ and includes
18 oblasts. This is one of the most densely populated and industrially developed areas of Russia. At present, over 90 billion tons of waste have accumulated in this area. Above 1000 waste disposal facilities, that is, landfills and waste disposal sites, exist there, with the bulk of them not included in the national registration list (The Government of Russian Federation, 2016).

One of the ways to solve the waste-management issue in Central Russia has been the construction of a limited number of large complex engineering facilities uniting an incinerator plant, a waste-reprocessing plant and a waste disposal (Ekzaryan, 2018; Kashperyuk et al., 2018). Such industrial complexes already exist in many well-developed countries. Sites for the allocation of such complexes are typically selected on the basis of sanitary standards, which constrain landfill allocation depending on the distance from settlements and water bodies, as well as topographic, geological and hydrogeological conditions (Ministry of Health of the Russian Federation, 2001; Djokanović et al., 2016; El Maguiri et al., 2016; Zelenović Vasiljević et al., 2012).

In terms of geology and hydrogeology, territories suitable for waste disposal include those where weakly permeable clay layers occur at the top of a geological massif, and the groundwater lies deeper than two meters below the surface. The presence of a thick clay strata in the upper part of the geologic massif appears to be the main condition of territory favorability for the allocation of waste management facilities because these strata prevent the permeating of contamination from the surface to the underlying aquifers. Experience demonstrates that ignorance of this requirement results in serious undesirable ecological consequences (Dzhamalov et al., 2018; Khmelchenko et al., 2018; Zaikanov et al., 2018).

For the CFD of the Russian Federation, the conditions (parameters) of natural protection of the geological environment from contamination have been analyzed, the principal types of geologicalhydrogeological conditions have been distinguished, and the criteria of assessing the favorability of the territory for the implementation of combined projects in waste management have been suggested.

\section{MATERIALS AND METHODS}

\section{Conceptual model of engineering geological assessment of the central Russia territory for the allocation of municipal solid waste treatment facilities}

Engineering geological assessment of potential sites for waste disposal proceeds from the idea that the occurrence of natural barriers in the geological crosssection can prevent contaminations from penetrating the surface down to the geological strata and groundwater. 
This prevention significantly enables the preservation of favorable ecological conditions around the waste disposal sites and waste treatment facilities. Clay strata operate as such natural barriers. Engineering geological studies consider the presence of thick clay strata in the upper part of geological massif to be the main condition of territory suitability for allocation of the waste treatment facilities (Goldberg, 1987).

Figure 1 lists the main steps of the methodology of territory assessment in Central Russia. In terms of structural geology, CFD is located within the Russian platform, within which the upper part of geological cross-section is composed of various stratigraphic and lithological sedimentary rock complexes of different age. To a depth of 50-60 m, the entire diversity of these complexes may be subdivided into several types depending on their lithology, age, and the degree of water content in the pre-Quaternary and Quaternary soils and rocks.

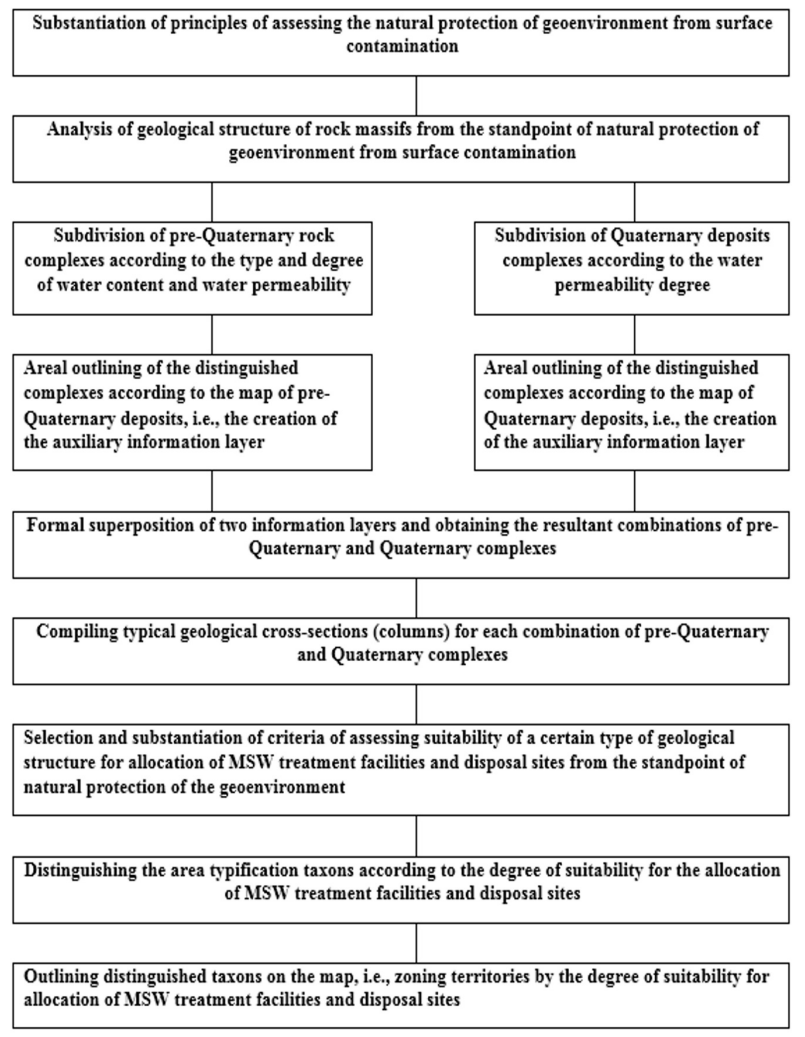

Fig. 1 Conceptual model of engineering geological assessment of the Central Russia territory for the allocation of MSW treatment facilities and disposal sites.

Mapinfo computer tools were used to create two auxiliary layers; one of the layers showing the preQuaternary rock complexes of different permeability and water content, and the other, the complexes of Quaternary deposits. The formal superposition of these layers permitted us to reveal their possible combinations. For each combination, the typical geological cross-section (column) was built showing the layers of different age, lithological composition and permeability. The input data for the compilation of these information layers and cross-sections included the small-scale archive geological maps for the Central Russia territory and other publications. In this work, we used the map data from the GIS atlas "The bowels of Russia" compiled at A.P. Karpinsky Russian Geological Research Institute (VSEGEI) and the State geologic map of the Russian Federation to a scale 1: 1000000 (VSEGEI, 1999, 2019).

Each type of geological structure (a typical geological cross-section) was referred to a certain category of territory suitability (a taxon) depending on the presence of low-permeable Quaternary and preQuaternary layers and the depth of their occurrence. Five taxons were distinguished corresponding to favorable, conventionally favorable, conventionally unfavorable, unfavorable and very unfavorable conditions from the viewpoint of MSW treatment projects. The assessment was performed proceeding from the geological structure depending on the mode of occurrence of low-permeable deposits in the upper part of geological massif.

The resultant zoning map manifests the outlines and indices of all types of geological structure, and the regions of different suitability (favorability) categories are distinguished in color (according to the traffic light principle). Thus, the map represents a highly informative document presenting not only the estimation criteria but also the generalized geological characteristics of each taxon.

\section{Assessment of Natural Protection of the Geological Environment}

The natural protection of geological environment from contamination coming from the surface was assessed depending on the presence of low-permeable deposits (capable to protect the geological environment from contamination penetrating from the surface) in the geological cross-section of pre-Quaternary and Quaternary deposits.

The pre-Quaternary deposits are subdivided into:

- low-permeable clay layers from the Jurassic age;

- unevenly permeable chalk and marl from the Cretaceous age and aleurolite-argillite gypsiferous rocks and gypsum from the Permian and Triassic ages;

- high-permeable sand and sandstone from the Neogene, Paleogene and Cretaceous ages;

- terrigenous-carbonate rocks from the Devonian and Carboniferous ages. 
Table 1. Types of ground massifs in the map of engineering geological zoning CFD

\begin{tabular}{|c|c|c|c|c|}
\hline $\begin{array}{l}\text { Quaternary } \\
\text { Quaternary } \\
\text { deposits }\end{array}$ & $\begin{array}{l}\text { Sand, moraine } \\
\text { loam, interbedding } \\
\text { sand and loam } \\
\text { (1) }\end{array}$ & $\begin{array}{c}\text { Sand } \\
(2)\end{array}$ & $\begin{array}{l}\text { Moraine loam, } \\
\text { interbedding sand } \\
\text { and loam } \\
\text { (3) }\end{array}$ & $\begin{array}{l}\text { Loessial sandy } \\
\text { loam and loam } \\
\text { (4) }\end{array}$ \\
\hline $\begin{array}{l}\text { Mainly sand and sandstone }(\mathrm{K}, \\
\mathrm{Pg}, \mathrm{N}) \text { water-bearing } \\
\text { I }\end{array}$ & I-1 & $\mathrm{I}-2$ & I-3 & I-4 \\
\hline $\begin{array}{l}\text { Marl, chalk (K) low water-bearing } \\
\text { and unevenly water-saturated } \\
\text { II }\end{array}$ & II-1 & II-2 & II-3 & II-4 \\
\hline $\begin{array}{l}\text { Mainly impermeable clay (J) } \\
\text { III }\end{array}$ & III-1 & III-2 & III-3 & - \\
\hline $\begin{array}{l}\text { Argillite, aleurolite, sandstone } \\
\text { locally gypsiferous, gypsum } \\
\text { (P-T), weakly and unevenly } \\
\text { water-bearing } \\
\text { IV }\end{array}$ & IV-1 & IV-2 & IV-3 & - \\
\hline $\begin{array}{l}\text { Water-bearing limestone, } \\
\text { dolomites with clay interlayers } \\
(\mathrm{D}-\mathrm{C}) \\
\mathrm{V}\end{array}$ & V-1 & $\mathrm{V}-2$ & V-3 & $V-4$ \\
\hline
\end{tabular}

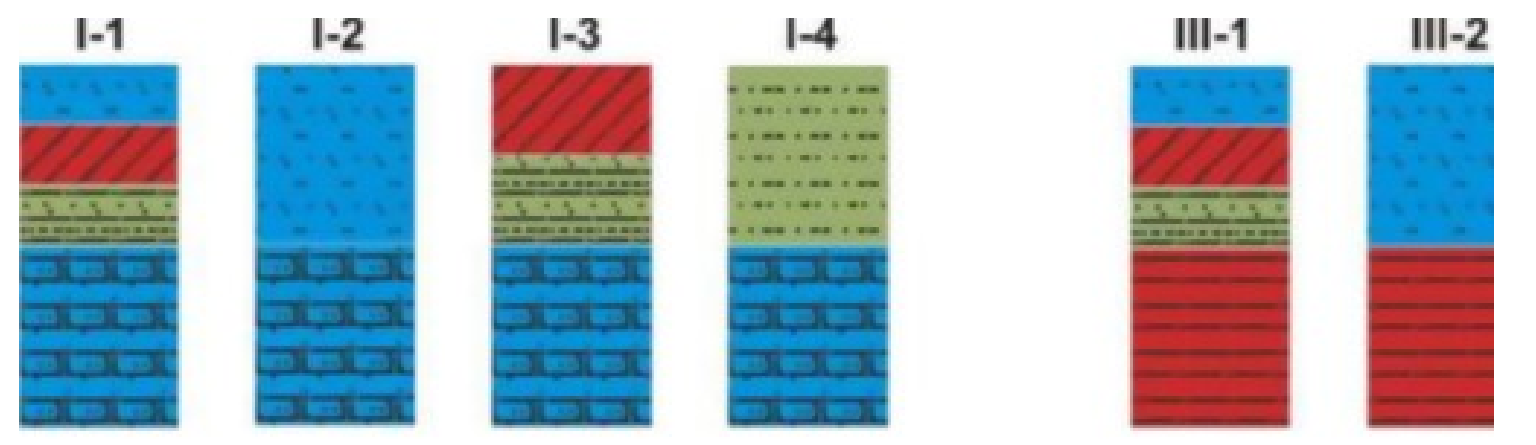
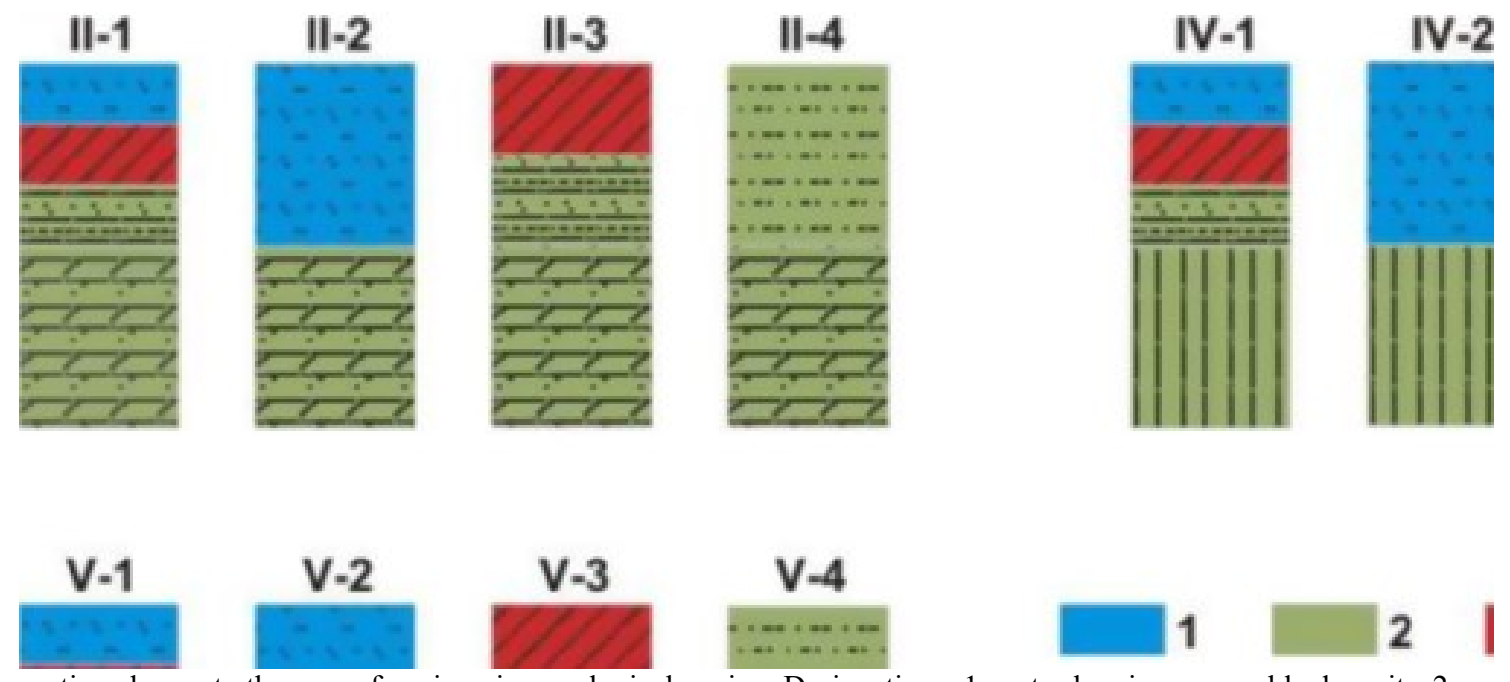

Fig. 2. Schematic columns to the map of engineering geological zoning. Designations: 1. water-bearing permeable deposits, 2 . weakly waterbearing and unevenly water-saturated deposits, 3. impermeable aquicludes. Quaternary deposits: 4. sand, 5. moraine loam, 6. interbedding sand and loam, 7. loessial sandy loam and loam. Pre-Quaternary deposits: 8. mainly sand and sandstone (K, Pg, N), 9. marl and chalk (K), 10. mainly clay $(\mathrm{J}), 11$. argillite, aleurolite, sandstone locally gypsiferous, gypsum (P-T), 12. limestone and dolomite with clay interlayers (D-C). 
Table 2. Typification of the Central Federal territory by its suitability for allocation of disposal sites and utilization facilities for MSW depending on engineering geological conditions

\begin{tabular}{cl}
$\begin{array}{c}\text { Types of geological structure according } \\
\text { to the suitability degree and } \\
\text { corresponding indices of typical } \\
\text { geological cross-sections }\end{array}$ & \multicolumn{1}{c}{ Specific features of engineering geological conditions } \\
$\begin{array}{c}\text { Favorable } \\
\text { III-3 }\end{array}$ & $\begin{array}{l}\text { Two aquiclude strata are distinguished in the cross-section, i.e., the } \\
\text { Quaternary moraine loam at the surface and Jurassic clay dividing the } \\
\text { Quaternary and Mesozoic water-bearing complexes. Geoenvironment is } \\
\text { protected from the contamination coming from the surface. }\end{array}$ \\
\hline $\begin{array}{c}\text { Quaternary moraine loam aquiclude is present on the top of the cross- } \\
\text { section, which is underlain by permeable either water-bearing or unevenly }\end{array}$ \\
and poorly water-saturated deposits of Quaternary and pre-Quaternary age. \\
II-3, & $\begin{array}{l}\text { Protection of geoenvironment from contamination is controlled by the } \\
\text { moraine layer thickness. }\end{array}$ \\
V-3, & $\begin{array}{l}\text { Quaternary deposits are represented by sandy-clayey water-bearing or } \\
\text { poorly and unevenly water-saturated soils. The groundwater aquifer is not } \\
\text { protected from contamination. The Quaternary massif is underlain by the }\end{array}$ \\
Jurassic clay aquiclude. The Mesozoic aquifer is protected from \\
contamination. \\
Protection of geoenvironment from contamination is controlled by the \\
depth of occurrence and the thickness of Jurassic clay layer.
\end{tabular}

The spatial position of these complexes is shown on the first auxiliary layer compiled in Mapinfo format. The analysis of Quaternary deposits was based on the presence of low-permeable loams of different genetic types and their position in the geological massif (Kashperyuk et al., 2018). Among Quaternary deposits, moraine loam forms the main low-permeable complex. On the second auxiliary information layer, the territories are outlined, where these soils lie at the surface or under alluvial and fluvioglacial sand. We have also defined the territories where mantle loam and sandy loam manifest a considerable stretch and thickness.

Superposition of the two auxiliary information layers resulted in 18 types of ground massifs depending on the stratigraphic and lithological specifics and the watercontent of pre-Quaternary and Quaternary complexes. These types formed the basis for the resultant estimation zoning of territory by the degree of favorability for allocation of MSW treatment facilities and disposal sites (Table 1). A schematic column was built for each zoning taxon (Figure 2), explaining the mode of occurrence of the distinguished geological and lithological complexes differing in its permeability. We distinguish: water-bearing and high-permeable deposits; low water-bearing and unevenly water-saturated deposits; and aquicludes or low-permeable deposits. In the geological cross-sections, the color stands for water content and water permeability, whereas the hatch designates stratigraphy and lithology.

\section{RESULTS}

\section{Zoning Territory by the Suitability of Engineering Geological Conditions for the Allocation of MSW Disposal Sites and Processing Facilities}

The typification of the Central Russian territory according to the favorability of allocating MSW treatment facilities and disposal sites is a result of the research performed (Table 2). The general small-scale (1:2500000) map of engineering geological zoning was compiled (Fig. 3). Favorable ground massifs are considered to be those that include two aquiclude strata, that is, the Quaternary moraine loam occurs close to the surface and the Jurassic clay. Thus, the quaternary and the Mesozoic water-bearing complexes are isolated 
from each other, and the geological environment is protected from contamination coming from the surface. These regions are outlined locally, mainly in the northern part of the territory.

We recognize territories as conventionally favorable if the Quaternary moraine loam occurs at the surface, being underlain by high-permeable deposits. The degree of protection of the geoenvironment from surface contamination is controlled by the moraine loam thickness at these sites. The areas of this kind are outlined in the northwest of the territory and on the interfluvial surfaces in its central part.

Conventionally unfavorable sites are those where ground massif is composed of sandy-clayey Quaternary deposits without any continuously stretching lowpermeable layers underlain by the Jurassic clay strata. The groundwater aquifer is prone to pollution at such sites, and the degree of protection of deep horizons is controlled by the thickness and depth of occurrence of the Jurassic clay. These regions are registered in the northern and eastern parts of the Moscow region.

We classify sites as unfavorable if the geological massif is composed of high-permeable Quaternary and pre-Quaternary deposits with locally spread lowpermeable layers. The geological environment in these areas is virtually unprotected from contamination. These areas include the bulk of the territory in the southwest and in the east of the Central Federal district, and local sites in the north.

Very unfavorable sites are those where the geological massif consists of only highly permeable and water-saturated deposits. At these sites the geological environment is not isolated from contamination coming from the surface. These sites are usually confined to river valleys, with alluvial deposits immediately overlying Carboniferous and Devonian carbonate rocks; or to the regions where Paleogene-Neogene sand and sandstone occur.

\section{DISCUSSION}

In the present study, using the example of Central Russia, we have attempted to demonstrate that the geological conditions as one of the criteria for site selection of MSW facilities requires special analysis due to substantial spatial variability. When characterizing sites, it appears not enough just to mark the soil and rocks occurring at the surface in the given territory and to point out the groundwater depth, as it is usually done upon zoning for waste disposal site selection (Djokanović et al., 2016; El Maguiri et al., 2016).

By assessing MSW disposal sites by the presence of one or several low-permeable layers in the geological cross-section, we are able to take into account the hazards of the contamination of the ground massif and ground water when assessing the territory.

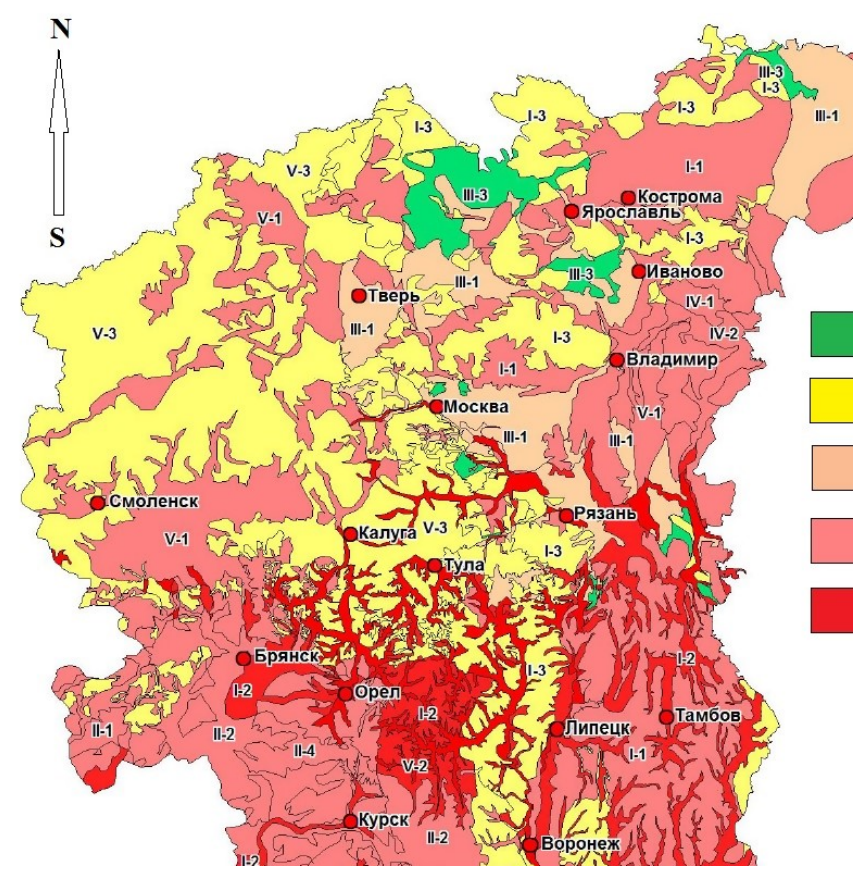

Fig. 3 The map of engineering geological zoning of the Central Federal district in Russia by the suitability of allocating MSW disposal sites and reprocessing facilities. Suitability grades: 1. favorable; 2. conventionally favorable; 3 . conventionally unfavorable; 4. unfavorable; 5. very unfavorable (The regions are described in detail in Table 2).

The map of the engineering geological zoning compiled on the basis of the proposed typification gives a general idea about the favorability of planned sites for the allocation of MSW reprocessing facilities in the Central Federal district. It is compiled in a digital form and it should be considered as an informational layer to be integrated in the general GIS based on the multicriteria principle for making decisions on waste disposal site selection. For the subsequent transition to the quantitative methods of multi-criteria analysis, it appears easy to assign scores to taxons according to their favorability degree.

In addition, the zoning map has its own value as an individual document reflecting the present-day state of the waste-disposal problem in Central Russia. The map analysis proves that the entire territories of Kursk and Belgorod oblasts are related to very unfavorable and unfavorable categories. That means no large sites can be identified within these territories, where the ground massif manifests natural protection from the contamination coming from the surface. In Bryansk, Kaluga, Orel, Lipetsk, Tambov, Voronezh, Ryazan, Vladimir and Kostroma oblasts, unfavorable and very unfavorable regions occupy more than half of the oblast territory.

Thus, for most of the Central Federal district, the construction of waste management facilities requires additional engineering measures for the protection of the geological environment from contamination. At 
present, many MSW disposal sites and landfills have been arranged within this territory without taking the geological conditions into account.

To minimize the risks of contamination, the specifics of the geological environment should be analyzed at the early stages of compiling waste-management GIS. In doing so, the geological environment should be considered as a massif of a complex structure with variable properties, as it is done in our research for the Central Russian region. The existing experience in GIS compilation demonstrates that the geological block is developed inadequately as a rule (Ghobadi et al., 2017; Khan \& Samadder, 2014; Khodaparast et al., 2018; Kontos et al., 2005). As proceeds from the analysis of international publications, the multi-criteria approach to selecting waste disposal sites, which is commonly employed all over the world, unfortunately underestimates the geological conditions of the territories being considered. At best, only the soil and rocks of the uppermost geological layer are taken into consideration, whereas the entire geological crosssection to a depth of anthropogenic impact is not considered (Deswal \& Laura, 2018; El Maguiri et al., 2016; Güler \& Yomralığlu, 2017; Rahmat et al., 2017). We suggest the typification of the geological environment according to the suitability (favorability) for the safe and reliable MSW disposal to be used at the early stage of planning the allocation of MSW treatment facilities. It permits, on the one hand, the capacity to formalize the assessment of geological conditions and, on the other hand, to take into account their variability by area and by the depth most comprehensively.

\section{CONCLUSION}

Proceeding from the research conducted, we may define the main points of methodology of assessing the natural protection of the geological environment from contamination within the framework of large ecological projects on the allocation of MSW utilization facilities:

- The assessment of the suitability of a territory for the allocation of MSW utilization facilities and waste disposal sites should obligatorily take into account the degree of natural protection from contamination provided by the geological environment.

- The degree of natural protection of the geological environment is assessed proceeding from the presence or absence in the geological massif of one or several low permeable rock strata preventing penetration of contaminants from the surface to groundwater aquifers, as well as the thickness and the depth of occurrence of these strata.

- Engineering geological zoning, including typifying territories by the specific features of geological and hydrogeological structures, assessing the favorability of each distinguished type, and zoning territories according to the geological criteria to determine their suitability to contain MSW utilization facilities and waste disposal sites appears to be a versatile method for assessing the natural protection of geological environment in vast territories.

To conclude, it is worth noting that small-scale maps or estimation schemes of engineering geological zoning can give a general idea of the suitability of the planned places for the allocation of waste disposal complexes. They point out the possible key sites for further investigation and give an overview of the volume of the necessary additional measures on geoenvironment protection from contamination upon the construction and running of these engineering facilities. These maps and schemes should be used at the early stages of projecting the MSW storage and management complexes.

\section{REFERENCES}

Cremiato, R., Mastellone, M. L., Tagliaferri, C., Zaccariello, L., \& Lettieri, P. (2018). Environmental impact of municipal solid waste management using Life Cycle Assessment: The effect of anaerobic digestion, materials recovery and secondary fuels production. Renewable Energy, 124, 180-188. doi:10.1016/j.renene.2017.06.033

Deswal, M., \& Laura, J. S. (2018). GIS based modeling using Analytic Hierarchy Process (AHP) for optimization of landfill site selection of Rohtak city, Haryana (India). Journal of Applied and Natural Science, 10(2), 633-642. doi:10.31018/jans.v10i2.1753

Djokanović, S., Abolmasov, B., \& Jevremović, D. (2016). GIS application for landfill site selection: A case study in Pančevo, Serbia. Bulletin of Engineering Geology and the Environment, 75(3), 1273-1299. doi:10.1007/s10064-016-0888-0

Dzhamalov, R. G., Medovar, Yu. A., \& Yushmanov, I. O. (2018). Vliyaniye ploshchadki utilizatsii tverdykh bytovykh otkhodov na kachestvo podzemnykh i poverkhnostnykh vod (na primere Vladimirskoy oblasti) xThe influence of municipal solid waste disposal site on the quality of ground- and surface water (by the example of Vladimir oblast). In Sergeevskie Chteniya: Issue 20. Proceedings of the Sci. Conference March 22, 2018 (pp. 175178). Moscow: RUDN Publ. (in Russian)

Ekzaryan, V. N. (2018). Metodologicheskiye osnovy zonirovaniya territoriy dlya vybora mest razmeshcheniya otkhodov [Methodological fundamentals of zoning territories for selecting places for the waste storage sites]. In Sergeevskie Chteniya: Issue 20. Proceedings of the Sci. Conference March 22, 2018 (pp. 97101). Moscow: RUDN Publ. (in Russian)

El Maguiri, A., Kissi, B., Idrissi, L., \& Souabi, S. (2016). Landfill site selection using GIS, remote sensing and multicriteria decision analysis: Case of the city of Mohammedia, Morocco. Bulletin of Engineering Geology and the Environment, 75(3), 1301-1309. doi:10.1007/s10064-016-0889-z

Ghobadi, M. H., Taheri, M., \& Taheri, K. (2017). Municipal solid waste landfill siting by using analytical hierarchy process (AHP) and a proposed karst vulnerability index in Ravansar County, west of Iran. Environmental Earth Sciences, 76(2), 68. doi:10.1007/s12665-017-6392-4

Goldberg, V. M. (1987). Vzaimosvyaz' zagryazneniya podzemnykh vod i prirodnoy sredy [Relationship between the contamination of 
groundwater and the environment]. Leningrad: Gidrometeoizdat. (in Russian)

Güler, D., \& Yomralığlu, T. (2017). Alternative suitable landfill site selection using analytic hierarchy process and geographic information systems: A case study in Istanbul. Environmental Earth Sciences, 76(20), 678. doi:10.1007/s12665-017-7039-1

Kashperyuk, I. V., Kozhevnikova, I. A., \& Anisimova, N. G. (2018). Inzhenerno-geologicheskoye rayonirovaniye Tsentral'nogo federal'nogo okruga v Rossii po usloviyam razmeshcheniya mest khraneniya i pererabotki TBO. [Engineering geological zoning of the Central Federal district in Russia by the conditions for allocation of MSW storage sites and processing facilities $\backslash$. In Sergeevskie Chteniya: Issue 20. Proceedings of the Sci. Conference March 22, 2018 (pp. 74-77). Moscow: RUDN Publ. (in Russian)

Kashperyuk, P. I., Makeeva, T. G., Akanov, A. V., Nikitina, K. V., \& ,Podlesnykh, A. I. (2018). Nekotoryye zakonodatel'nyye i prirodookhrannyye voprosy pri organizatsii ob"yektov pererabotki i zakhoroneniya TBO v Moskovskoy oblasti. [Some legislative and nature-conservation issues in the arrangement of MSW reprocessing and disposal sites in the Moscow region]. In Sergeevskie Chteniya: Issue 20. Proceedings of the Sci. Conference March 22, 2018 (pp. 71-73). Moscow: RUDN Publ. (in Russian)

Khan, D., \& Samadder, S. R. (2014). Municipal solid waste management using Geographical Information System aided methods: A mini review. Waste Management \& Research, 32(11), 1049-1062. doi:10.1177/0734242X14554644

Khmelchenko, E. G. (2018). Problemy utilizatsii tvordykh kommunal'nykh otkhodov $\mathrm{v}$ rossiyskoy federatsii i puti ikh resheniya [Problems of utilization of solid municipal waste in the Russian Federation and ways to solve them]. Munitsipal'naya Akademiya [Municipal Academy], (2), 110-114. (in Russian)

Khmelchenko, E. G., ,Kazakova, I. G., ,Bogomolov, Yu. G., Savelyev, A. F., Medovar, Yu. A., \& Yushmanov, I. O. (2018). O vliyanii poligona tvordykh kommunal'nykh otkhodov na kachestvo podzemnykh vod $\mathrm{v}$ Moskovskoy i Vladimirskoy oblastyakh [On the influence of the range of solid utility waste on the quality of underground water in the Moscow and Vladimir region]. Munitsipal'naya Akademiya [Municipal Academy], (3), 55-62. (in Russian)

Khodaparast, M., Rajabi, A. M., \& Edalat, A. (2018). Municipal solid waste landfill siting by using GIS and analytical hierarchy process (AHP): A case study in Qom city, Iran. Environmental Earth Sciences, 77(2), 52. doi:10.1007/s12665-017-7215-3

Kontos, T. D., Komilis, D. P., \& Halvadakis, C. P. (2005). Siting MSW landfills with a spatial multiple criteria analysis methodology. Waste Management, 25(8), 818-832. doi:10.1016/j.wasman.2005.04.002

Ministry of Health of the Russian Federation (2001). Sanitary Rules SP 2.1.7.1038-01 Hygiene requirements for the arrangement and maintenance of solid domestic waste disposal sites. Retrieved from

https://gostperevod.com/catalog/product/view/id/339144/s/sp-2-17-1038-01/category/44/ (in Russian)

Nakhaei, M., Amiri, V., Rezaei, K., \& Moosaei, F. (2015). An investigation of the potential environmental contamination from the leachate of the Rasht waste disposal site in Iran. Bulletin of Engineering Geology and the Environment, 74(1), 233-246. doi:10.1007/s10064-014-0577-9

Ogola, J. S., Chimuka, L., \& Tshivhase, S. (2011). Management of municipal solid wastes: a case study in Limpopo province, South Africa. Integrated Waste Management - Volume I. doi:10.5772/18655

Osipov, V. I. (2019). Management of solid municipal waste as the federal ecological project. Geoecology. Engineering Geology. Hydrogeology. Geocryology, (3), 3-11. doi:10.31857/S08697809201933-11 (in Russian)

Rahmat, Z. G., Niri, M. V., Alavi, N., Goudarzi, G., Babaei, A. A., Baboli, Z., \& Hosseinzadeh, M. (2017). Landfill site selection using GIS and AHP: A case study: Behbahan, Iran. KSCE Journal of Civil Engineering, 21(1), 111-118. doi:10.1007/s12205-0160296-9

The Government of Russian Federation. (2016, March 16). Postanovleniye Pravitel'stva RF N 197 “Ob utverzhdenii trebovaniy $\mathrm{k}$ soderzhaniyu i strukture territorial'nykh skhem obrashcheniya $\mathrm{s}$ otkhodami, $\mathrm{v}$ tom chisle tverdymi bytovymi otkhodami”. [Decision of the RF Government N 197 'Adoption of requirements to the content and structure of territorial schemes of waste management, including solid municipal waste']. (in Russian)

VSEGEI. (1999). State Geological Map of the Russian Federation.

VSEGEI. (2019). GIS atlas of current geological information, Central Federal district. Retrieved from http://atlaspacket.vsegei.ru/\#f78cf9c49e5ef7fa0

Yannah, M., Martens, K., Van Camp, M., \& Walraevens, K. (2019). Geophysical exploration of an old dumpsite in the perspective of enhanced landfill mining in Kermt area, Belgium. Bulletin of Engineering Geology and the Environment, 78(1), 55-67. doi:10.1007/s10064-017-1169-2

Zaikanov, V. G., Zaikanova, I. N., \& Buldakova, E. V. (2018). Geoekologicheskiy i landshaftno-ekologicheskiy analiz poligonov v Moskovskoy oblasti [Geoecological and landscape ecological analysis of landfill sites in Moscow oblast]. In Sergeevskie Chteniya: Issue 20. Proceedings of the Sci. Conference March 22, 2018 (pp. 65-73). Moscow: RUDN Publ. (in Russian)

Zelenović Vasiljević, T., Srdjević, Z., Bajčetić, R., \& Vojinović Miloradov, M. (2012). GIS and the Analytic Hierarchy Process for Regional Landfill Site Selection in Transitional Countries: A Case Study From Serbia. Environmental Management, 49(2), 445-458. doi:10.1007/s00267-011-9792-3 